\title{
Evaluation of the Strategy for the Implementation of Solar Power Plants in Indonesia Using SWOT Analysis
}

\author{
Randy Maulana Nasir, Rinaldy Dalimi* \\ Energy System Engineering, Universitas Indonesia
}

*Corresponding author:

E-mail:

rndalimi@gmail.com

\begin{abstract}
The demand for electricity in Indonesia is currently growing very massively with an increase in the population of 270 million people, rapid economic growth, as well as the increasing rate of urbanization and large-scale industrialization. Referring to the RUEN, in 2025 renewable energy is projected to increase from $7 \%$ to $23 \%$, with the current realization at $11.51 \%$ by 2020 . In this study, the SWOT method is used to evaluate strategies that have been implemented internally (strengths, weaknesses) and external (opportunities and threats), to achieve the RUEN Target. Based on the results of the study found 5 success factors for the implementation of PV mini-grid, namely economy, environment, marketing, politics, social, and technology. Furthermore, from the SWOT analysis obtained: First, for the social aspect, namely related to population and human resources, each recommended strategy is an aggressive strategy. Second, for the economic aspect, which is related to potential, and the economy, each recommended strategy is an aggressive strategy and a turnaround strategy. Third, for the environmental aspect, the recommended strategy is a diversification strategy. Fourth, for the political aspects, namely regulations and incentives, the recommended strategy is a turnaround strategy. Fifth, for the technological aspect, namely technology, and industrialization, the recommended strategy is aggressive.
\end{abstract}

Keywords: Evaluation, solar power plants, SWOT Analysis

\section{Introduction}

The increase in the number of Indonesian population is linear every year. In the last ten years (2010-2020), Indonesia's population growth rate is 1.25 percent per year. There is a slowdown in the population growth rate of 0.24 percentage points when compared to the population growth rate in the 2000-2010 period which was 1.49 percent, then decreased below $1 \%$ in the $2020-2040$ period and after 2040 the growth was below $0.5 \%$. Indonesia's economic growth in the next few years is supported by increasing domestic demand, including consumption and investment, as well as better export growth, including in the manufacturing sector, which is the main energy consumer in the industrial sector.

The Government of Indonesia's commitment in participating with the international community to reduce greenhouse gas emissions was stated by the President of the Republic of Indonesia at the Conference of Parties 15 in 2009 that Indonesia would reduce GHG emissions by $26 \%$ (with its efforts) and by 41\% (if received international assistance) by 2020 (Sugiyono, 2016). The reduced production of fossil energy, especially oil, and the global commitment to reducing greenhouse gas emissions, encourage the Government to continuously increase the role of new and renewable energy as part of maintaining energy security and independence. According to PP No. 79 of 2014 concerning National Energy Policy, the target for the new and renewable energy mix in 2025 is at least $23 \%$ and $31 \%$ in 2050 . Indonesia has a large enough potential for new and renewable energy to achieve the primary energy mix target, as shown in Table 1. 
Table 1. Potential of renewable energy in Indonesia

\begin{tabular}{cc}
\hline Energy type & Potency \\
\hline Heat power & $94.3 \mathrm{GW}$ \\
Geothermal & $28.5 \mathrm{GW}$ \\
& PLT Bio: $32.6 \mathrm{GW}$ and \\
Sun & BBN: 200 thousand Bph \\
Wind & $60.6 \mathrm{GW}$ \\
Ocean energy & $17.9 \mathrm{GW}$ \\
\hline
\end{tabular}

Referring to the EBT (new renewable energy) mix according to the RUEN 2025, which is $23 \%$ with a target of $6.5 \mathrm{GW}$ for solar PV, with the actual current implementation of $11.51 \%, 1 \mathrm{GW}$ per the year 2020 (Source: Performance Performance EBTKE 2020). Furthermore, in terms of the cost of generating PLTS, currently, it ranges from 6-12 sen/kWh compared to the cost of generating PLTU which only ranges from 4-6 sen/kWh. This problem led to the issue of the policy of the price of electricity obtained from solar plants. Until now, the tariff set by the government has not been considered profitable and is still much lower than the tariff for electricity originating from the PLTU. However, on the other hand, the solar energy sector has enormous potential if it is managed optimally (Kennedy, 2018). The long-term benefits that will be obtained also cover various sectors, such as the economic and environmental sectors. It can be concluded that to achieve the previously planned target in 2025 , which is $23 \%$ with a target of $6.5 \mathrm{GW}$, it is necessary to re-evaluate the strategies that have been implemented in Indonesia both from an internal side (strengths, weaknesses) and externally (opportunities and opportunities). threats), to determine the best strategy, right on target (Dobrotkova et al., 2018).

\section{Material and Methods \\ Material}

The concept of Solar PV as renewable energy

The sun is heat energy that has been conventionally used by humans since time immemorial which can be obtained for free only in unlimited quantities. The solar thermal energy that is available for free and is easy to use has existed since the creation of this earth. Initially, it received little appreciation and was considered normal, especially before the invention of solar cell technology. However, after solar energy can be converted to electrical energy using solar cells, solar energy is more appreciated. Then the electrical energy produced from solar cells can be converted again into motion energy, light, and heat. After that, it was felt that solar energy has extraordinary potential that can meet the energy needs of humans around the world later. even on the other hand, after the price of electrical energy from the sun is cheaper than other energy sources. When solar radiation hits the photovoltaic material, due to the nature of the material, it can cause the movement of electrons to produce an electric current.

\section{Implementation of solar PV in Developed VS developing countries}

In 2019 the solar PV market is expected to increase by $12 \%$ to approximately 115 GWI. The decade ends with strong demand in Europe, the United States, and emerging markets around the world, more than making up for the substantial decline in China, the largest single market. Excluding China, the global market for solar PV grew by approximately 44\% in 2019. The global total is $627 \mathrm{GW}$, which includes both on- and off-grid capacity, compared to a total of less than $23 \mathrm{GW}$ just 10 years earlier. The demand for solar PV is spreading and growing as it becomes the most competitive option for power generation in an increasing number of locations - for residential and commercial applications and increasingly for utility-scale projects - even without taking into account the external costs of fossil fuels. In some markets, this also applies to solar-plus-storage. In 2019, it is estimated that 18 countries added at least 1 GW of new capacity, up from 11 in 2018, and all continents contributed significantly to global growth. By the end of 2019, at least 39 countries had a cumulative capacity of $1 \mathrm{GW}$ or more, up from 31 countries one year earlier. 


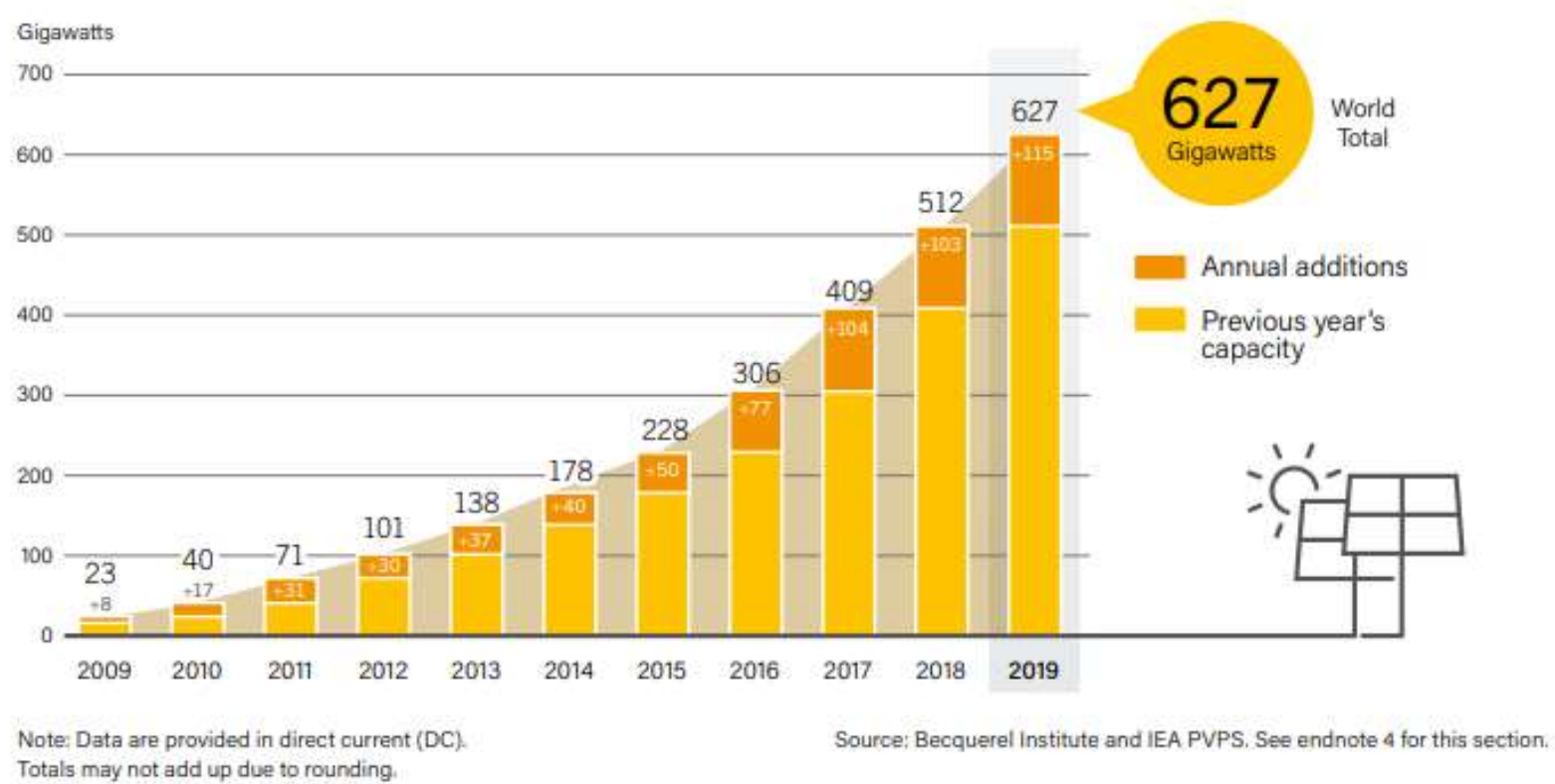

Figure 2. Global solar PV Capacity 2009 - 2019

In some countries, solar PV is already playing an important role in power generation. By the end of 2019, 22 countries had sufficient capacity in operation to meet at least 3\% of their electricity needs with solar PV, and 12 countries had enough for at least $5 \% .10$ For the full year, solar PV accounts for approximately $10.7 \%$ of the total generation in Honduras and a substantial share also in Italy (8.6\%), Greece (8.3\%), Germany $(8.2 \%)$, Chile $(8.1 \%)$, Australia $(7.8 \%)$ and Japan (7.4\%), and others. Sufficient capacity was operational worldwide by the end of the year to generate approximately $2.8 \%$ of global electricity generation. In most countries, there is still a need for support schemes for solar PV, as well as for adequate regulatory frameworks and policies governing grid connections. Government policies - in particular feed-in tariffs (FITs), feed-in premiums, and tenders - continued to drive large parts of the global market in 2019.

\section{Solar energy implementation in Indonesia}

Indonesia is one of 195 countries that signed the Paris Agreement and one of 164 countries plus the European Union, which ratified it. With this international commitment, Indonesia has a national target to reduce greenhouse gas emissions by $29 \%$ from business as usual conditions in 2030 with its efforts and a further $41 \%$ with international assistance. This commitment requires Indonesia to consistently develop renewable energy, especially in the electricity sector. With the perspective of energy as development capital, renewable energy has an important role in driving a green, sustainable, and low-carbon economic system. This long-term development with awareness has become a development trend around the world, addressing the increasing population, human needs, and human activities that cause environmental damage. Indonesia has renewable energy potential spread throughout Indonesia, including solar energy sources, water and micro-hydro energy sources, wind energy sources, geothermal energy sources, ocean wave energy sources, and biomass energy sources. In the context of sustainable development, current energy consumption also has the potential for energy efficiency and conservation (Dailami, 2020). 


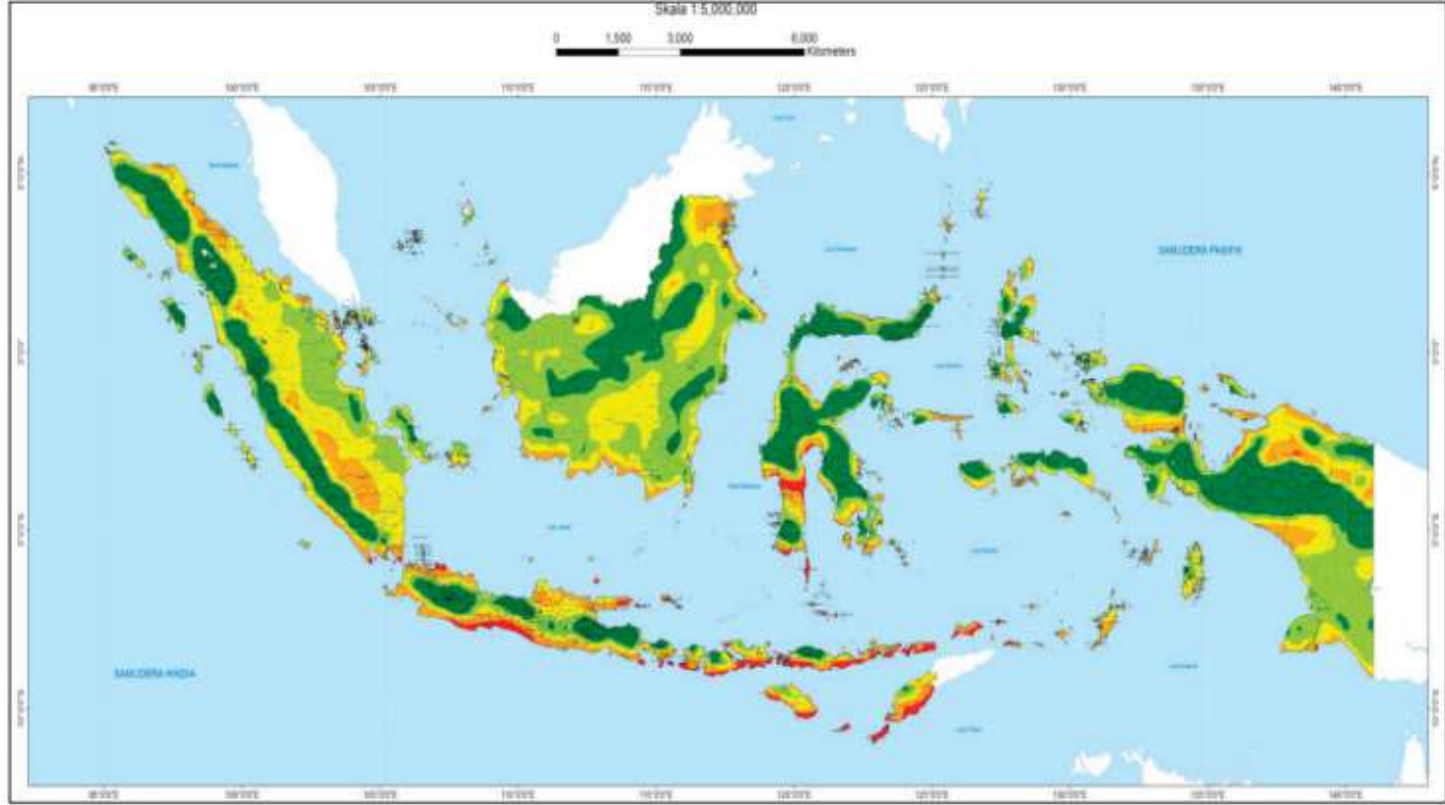

Figure 3. Solar energy implementation in Indonesia

Table 2. Solar technical potential per Province

\begin{tabular}{|c|c|c|c|}
\hline No & Province & Theoretical Potential (MW) & Technical Potential (MW) \\
\hline 1 & Aceh & 52.540 & 7.881 \\
\hline 2 & Bali & 8.362 & 1.254 \\
\hline 3 & Bangka-Belitung & 18.736 & 2.810 \\
\hline 4 & Banten & 16.407 & 2.461 \\
\hline 5 & Bengkulu & 23.167 & 3.475 \\
\hline 6 & D.I Yogyakarta & 6.639 & 996 \\
\hline 7 & DKI Jakarta & 1.499 & 225 \\
\hline 8 & Gorontalo & 8.122 & 1.218 \\
\hline 9 & Jambi & 58.977 & 8.847 \\
\hline 10 & Jawa Barat & 60.660 & 9.099 \\
\hline 11 & Jawa Tengah & 58.355 & 8.753 \\
\hline 12 & Jawa Timur & 68.903 & 10.335 \\
\hline 13 & Kalimantan Barat & 134.089 & 20.113 \\
\hline 14 & Kalimantan Selatan & 40.209 & 6.031 \\
\hline 15 & Kalimantan Tengah & 56.390 & 8.459 \\
\hline 16 & Kalimantan Timur & 89.859 & 13.479 \\
\hline 17 & Kalimantan Utara & 30.956 & 4.643 \\
\hline 18 & Kepulauan Riau & 5.019 & 753 \\
\hline 19 & Lampung & 51.754 & 7.763 \\
\hline 20 & Maluku & 14.920 & 2.238 \\
\hline 21 & Maluku Utara & 13.466 & 2.020 \\
\hline & To be continued & & \\
\hline
\end{tabular}




\begin{tabular}{lccc}
22 & Nusa Tenggara Barat & 20.243 & 3.036 \\
23 & Nusa Tenggara Timur & 66.205 & 9.931 \\
24 & Papua & 48.478 & 7.272 \\
25 & Papua Barat & 13.567 & 2.035 \\
26 & Riau & 42.047 & 6.307 \\
27 & Sulawesi Barat & 11.178 & 1.677 \\
28 & Sulawesi Selatan & 50.586 & 7.588 \\
29 & Sulawesi Tengah & 41.244 & 6.186 \\
30 & Sulawesi Tenggara & 26.113 & 7.588 \\
31 & Sulawesi Utara & 14.805 & 6.186 \\
32 & Sumatera Barat & 39.323 & 3.917 \\
33 & Sumatera Selatan & 114.883 & 17.233 \\
34 & Sumatera Utara & 79.006 & 11.851 \\
& TOTAL & 1.359 .988 & 207.898 \\
\hline
\end{tabular}

Source: RUEN

Despite the huge potential of solar power generation across Indonesia, the scale of this sector is largely untapped, with around $150 \mathrm{MW}$ of solar capacity installed at the end of 2019. Solar power is estimated to have a potential of over $200 \mathrm{GW}$ Solar photovoltaic projects of utility, commercial and industrial size has a great opportunity to immediately build economies of scale to support the fulfillment of the renewable energy target of $23 \%$ by 2025 . RUPTL $2019-2028$ has targeted a capacity of $908 \mathrm{MW}$ by 2028. Furthermore, there is significant potential for small-scale solar power to contribute as a source of impact lower environmental levels of rural electricity and increased electricity in remote parts of the country. Solar power, with and without storage, can be used to further ensure reliability. A pilot solar power plant project is being explored in the planning to achieve $100 \%$ electrification.

The lack of consistent and promotive policies to develop renewable energy projects has contributed to the slow increase in solar energy, despite projections and plans to increase the share of this energy option. Recent progress has been made by the government to support the development of this resource, including a new policy to provide a framework for rooftop solar systems (footnote 25) and allow surface reservoirs to be used for floating solar. There is also interest in developing domestic power sources for batteries and other storage technologies to accommodate the intermittency of solar renewable energy.It can be concluded that we still have a long way to go towards implementing Solar Energy in Indonesia, with the condition of Indonesia being an archipelagic country, solar is one of the great opportunities in terms of its potential. Furthermore, this analysis will evaluate the strategy that has been planned and implemented and recommend the best strategy on target. Furthermore, the results of this study can be used as a reference and recommendation for the competent agency in formulating government policies \& regulations related to the implementation of solar PV in Indonesia..

\section{Methods}

The purpose of this study is to evaluate the implementation strategy of solar PV in Indonesia that has been planned or implemented previously, both in terms of strengths, weaknesses, opportunities and threats and to provide recommendations for the best strategy on target to achieve the planned energy mix target. Furthermore, the results of this study can be used as a reference and recommendation for the competent agency in formulating government policies \& regulations related to the implementation of solar PV in Indonesia. 
It can be seen from the picture below that the flow of completion of this research is: First, conduct a desktop study related to the actual condition of solar PV implementation in Indonesia (Exisiting Strategy, Plans from non-profit organizations, previous research). Second, analysis of internal and external factors of solar PV implementation in Indonesia. Third, conduct a survey related to the implementation of solar PV in Indonesia based on predetermined internal and external factors. Fourth, quantify data based on survey results, and determine strategy based on survey results. And the last step is to determine recommendations based on the results of calculations with SME (Subject Metter Expert) using Delphi techniques (Interviews), and citing recommendations from previous desktop studies. Furthermore, the detailed process can be seen in Fig. 4

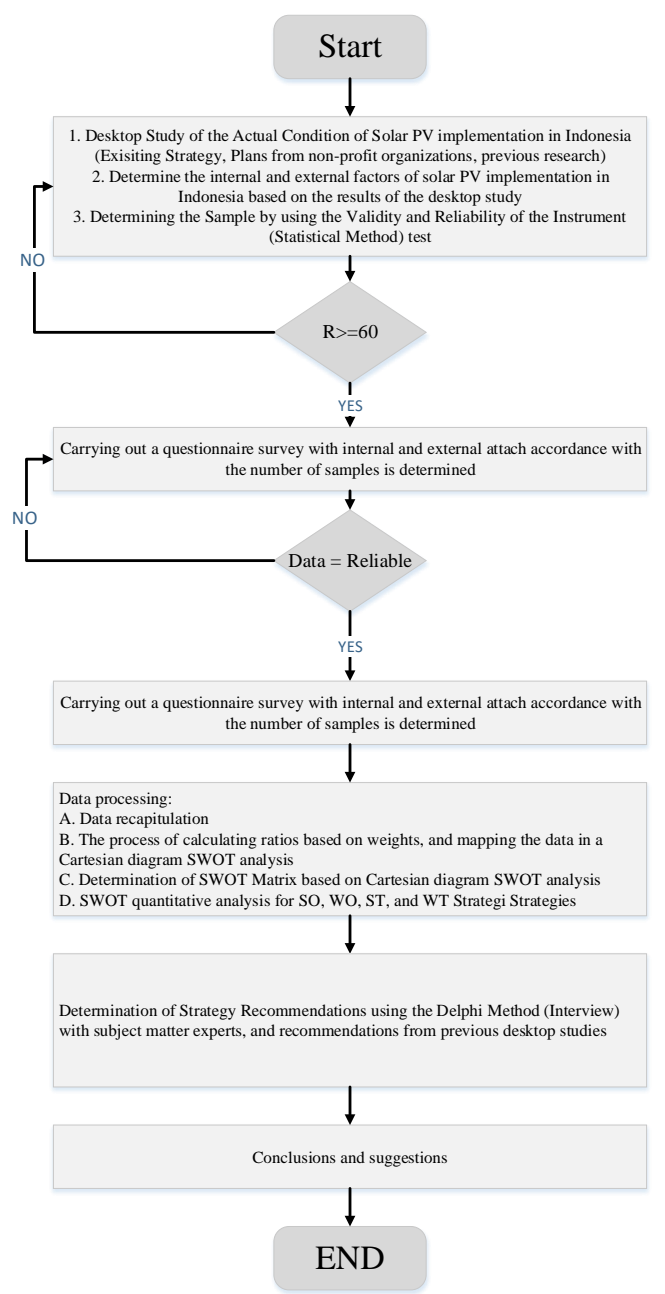

Figure 3. Research methodology

\section{Results and Discussion}

\section{Thorough analysis of each aspect and its recommendations}

\section{Social}

Population changes greatly affect the magnitude and composition of energy demand, both directly and as a result of their impact on economic development. During the last two decades, Indonesia's population growth rate has tended to slow down. Based on the publication of Indonesia's population projections for 2010-2045 (BPS - Bappenas 2014), Indonesia's population growth for the 2015-2020 period is more than 1\%, then decreases below $1 \%$ in the $2020-2040$ 
period and after 2040 its growth will be below $0.5 \%$. With the increase in the economy and population, the final energy demand for the commercial sector is expected to continue to increase with the highest growth rate compared to other sectors.

Examining the Field, Employment Opportunities and Human Resources IRENA estimates that global solar PV employment will increase by $4 \%$ to reach 3.8 million jobs in 2019.3 Of the ten leading countries shown in Figure 4, seven of them are Asia. Overall, nearly 3.1 million solar PV jobs (83\% of the global total) are in Asia, followed by 6.5\% North America, 4.4\% Europe and 3.7\% Africa. Together, the top ten countries are home to approximately $87 \%$ of the world's solar PV workforce, indicating that deployment and manufacturing continues to be concentrated in a few countries. The global total includes an estimated 372,000 off-grid jobs for South Asia and parts of Africa (IRENA, 2019).

The challenges that will be faced related to social aspects are:

- Technical competence of Human Resources which still needs to be improved.

- The solar PV assembly industry is still rare in Indonesia

- Lack of public knowledge regarding solar PV

- Perception of solar energy as "expensive" energy.

The recommendations that the author conveys are:

- Intensify studies related to the elasticity of energy growth from each region so that the government can be more precise in determining the energy development each region

- The government cooperates with educational institutions to provide facilities in training or socialization to residents regarding how to install and maintain Solar PV.

- Conduct Transferring technology knowledge from cooperating countries so that not only technology can be obtained by Indonesia.

\section{Economic}

Indonesia has enormous solar energy potential estimated at over $500 \mathrm{GW}$-more than any other renewable source in the country. The International Renewable Energy Agency (IRENA) (2018) estimates that Indonesia could develop up to $3.1 \mathrm{GW}$ of solar energy per year from 2016 to 2030 and reach $47 \mathrm{GW}$ of solar capacity by 2030 . This potential should be sufficient to meet the National General Energy Plan National Energy [RUEN]) targets $6.5 \mathrm{GW}$ of solar power by 2025.

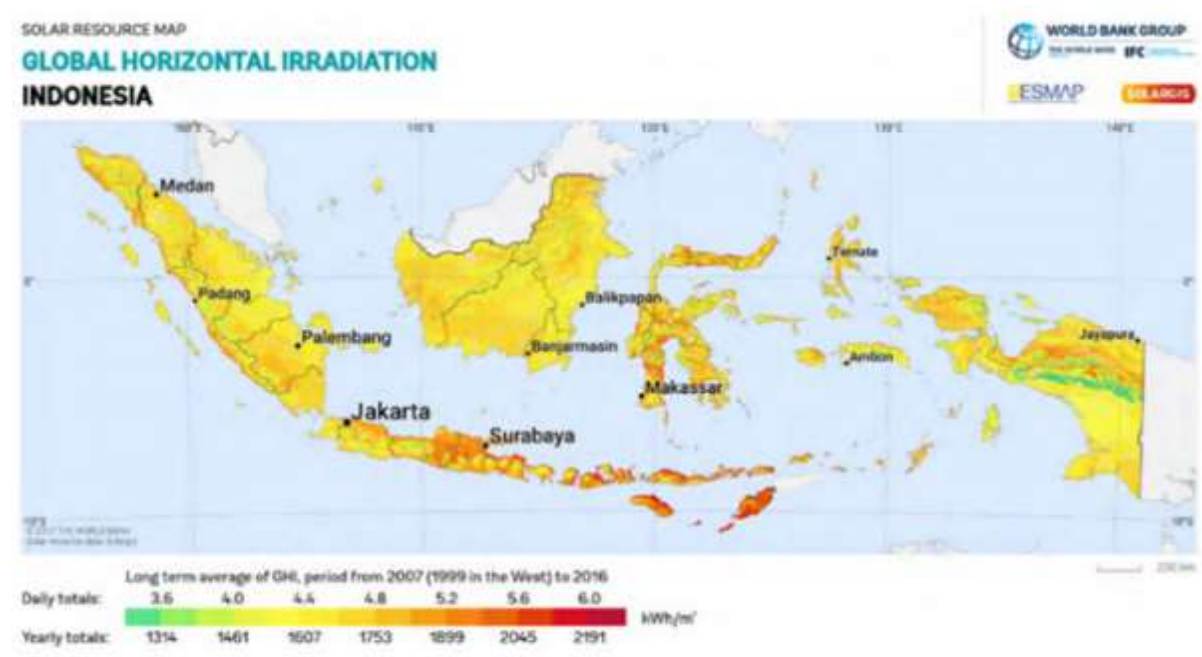

Figure 4. Peta Global Horizontal Irradiation Indonesia (Source: Solargis, 2017) 


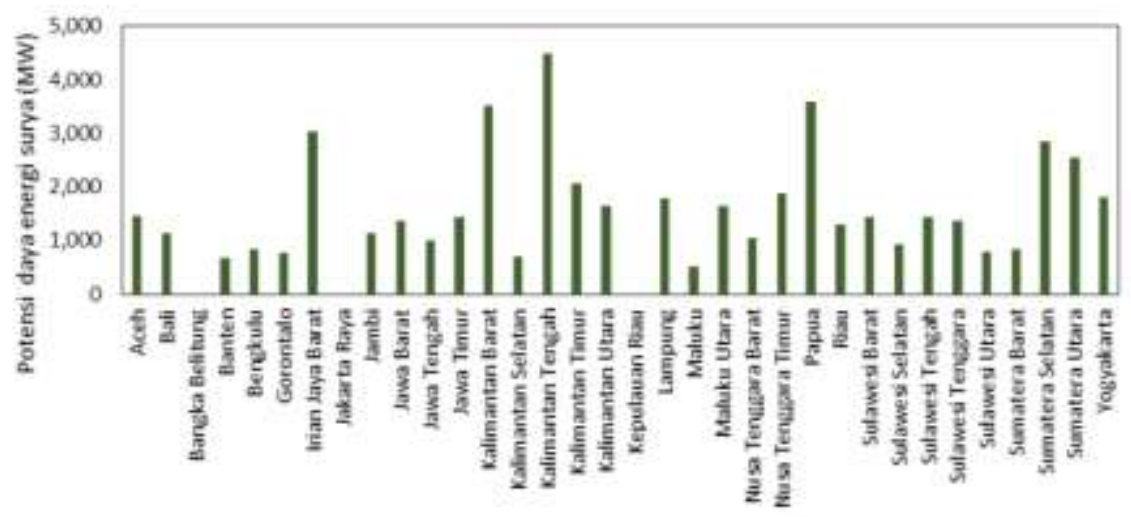

Figure 5. Potensi daya surya untuk setiap Provinsi di Indonesia (Source: UGM Center for Energy Studies, 2018)

Despite the huge potential of solar power generation across Indonesia, the scale of this sector is largely untapped, with around $150 \mathrm{MW}$ of solar capacity installed by the end of 2019. It is expected that with the potential of solar power it is estimated that there will be more than 500 GW of utility-sized solar photovoltaic projects. , commercial and industrial sectors have great opportunities to immediately build economies of scale to support the fulfillment of the renewable energy target of $23 \%$ by 2025 . Overall, by 2025 Indonesia requires a total investment of IDR 5.05 trillion in solar power plants with a total installed capacity of $175.83 \mathrm{MW}$. The largest estimated installed capacity is in the Java area, which is $89.23 \mathrm{MW}$, which is equivalent to an investment value of Rp2,524 billion.

Table 4. Estimated PLTS investment needs per region

\begin{tabular}{|c|c|c|}
\hline Area & $\begin{array}{l}\text { Installed capacity } \\
\text { PLTS } 2025 \text { (MW) }\end{array}$ & $\begin{array}{r}\text { Investment needs } \\
\text { (Rp Miliar) }\end{array}$ \\
\hline Aceh/Sumatera Utara & 8,73 & 252,83 \\
\hline Jambi-Sumbar-Sulsel-Babel & 23,64 & 679,36 \\
\hline Kalimantan & 21,32 & 617,45 \\
\hline Jawa & 89,23 & $2,524,10$ \\
\hline Bali-Nusa & 7,16 & 205,10 \\
\hline Sulawesi & 15,47 & 450,52 \\
\hline Ambon-Maluku & 1,57 & 46,87 \\
\hline Papua & 8,70 & 273,69 \\
\hline TOTAL & 175,83 & $5.050,00$ \\
\hline
\end{tabular}

Source: UGM Center for Energy Studies (2018)

The challenges that will be faced related to Economic aspects are:

- Geographical and natural conditions that affect the infrastructure development process

- The size of the area in Indonesia that is the target of infrastructure development 
- Unfair equity IRR leading to project termination

The recommendations that the author conveys are:

- For PV energy potential centrally in RUEN, it needs to be incorporated into the local government, because there is a lot of overlap between RUEN and RUED from the local government, which has an impact on the inaccurate RUPTL made by PLN/Directorate General of Electricity.

- Strengthen local renewable project financing, including providing government loan guarantees for large renewable projects, loan funds, and guarantees with high initial costs and risk guarantees.

- The need for government policies in providing low bank loan interest rates for domestic solar panel industry players

\section{Environmental}

The continuous increase in Greenhouse Gas (GHG) emissions has an impact on increasing global temperatures and climate change. For Indonesia, climate change results in extreme climates that trigger disasters. The National Disaster Management Agency (BNPB) noted that hydrometeorological disasters that occurred throughout 2020 in the form of floods as many as 1,080 cases, drought 29 cases, landslides 577 cases, tornadoes 880 cases, and tidal waves or abrasion 36 cases. These various hydrometeorological disasters have caused economic losses (Kompas, 15 March 2021). To reduce the increase in global temperature, it is necessary to reduce emissions. In the aspect of sustainable development, Indonesia faces challenges in the sustainability of its economic growth. The heavy dependence on natural resources, especially non-renewable ones, is reflected in their share of GDP, the composition of exports, and state revenues. Dependence that continues to pose a threat in the future as the availability of resources is running low and a sharper strategy is needed to shift to a sector that will ensure the sustainability of the Indonesian economy in the future. Accelerating the transition from coal generation to renewable energy (including solar energy) can help reduce air pollution, especially particulate matter that is harmful to humans.

The challenges that will be faced related to Enviromental aspects are:

- The materials used in solar panels will become waste if the equipment is damaged. The components and materials that make up the tool will be disposed of and can pollute the environment.

- The components in solar panels are metal that must be mined, the more solar panels are needed, the more metal mining has to be done.

- Reflection of sunlight from solar panels that are harmful to living things.

- The significant amount of government financial assistance (subsidy) makes it difficult for renewable

The recommendations that the author conveys are:

- The need for special attention and further research on aquatic biota related to the environmental impact (post-effect) on the installation of PV in water areas (seas and lakes).

- Development of recycled crystalline silicon, a material used in more than $90 \%$ of installed PV systems in a very pure form. It accounts for about half of the energy, carbon footprint, and cost of producing PV modules but with a shorter lifetime.

- Green investment policies should also be put in place to attract domestic and international investors, which has experienced a large increase over the past decade.

- Encouraging the reallocation of energy subsidies from fossil-fuel generation to Greenbased, in this case, Solar PV Development. 


\section{Politic}

In terms of regulations and policies, many electricity sector policies awaiting implementation are not in harmony with each other or conflict with related non-energy regulations. Several official plans, including RUEN, RUPTL, and RUKN, rely on unrealistic input data assumptions and provide conflicting and unattainable targets. Indonesia has been working to improve the reliability of the MEMR energy data and strengthen the regulatory review process to ensure consistency across regulations. The Indonesian constitution requires the government to control the energy sector, but there is no independent body to transparently recommend tariffs, review investments, oversee PLN procurement and operations, provide policy advice, and evaluate whether the private sector or SOEs should build new infrastructure. Many SOEs are having financial difficulties.

Furthermore, from the aspect of subsidies or incentives, the current government incentives are more focused on fossil energy, where the government still prioritizes fossil power generation, where the significant amount of government financial assistance (subsidies) is around US\$664 million in 2015 (IISD 2018). Without incentives, the estimated economic price of PLTS in almost all regions is still far above the regional average BPP, both BPPs that have been subject to the 85 percent rule and BPPs that have not been subject to the 85 percent rule. This shows that without incentives, the determined BPP has not been able to attract investors to invest in PV mini-grid in all regions.

The challenges that will be faced related to Politic aspects are:

- Policy uncertainty - An often-cited obstacle is a frequency with which the government changes direction, policies, and regulations.

- The amount of fossil industry subsidies

- Corruption is still an issue in Indonesia.

The recommendations that the author conveys are:

- Establish regulations and provide tax subsidies for alternative energy power generation.

- Designing better renewable energy compensation for PLN to encourage greater uptake of renewable energy by the agency.

- Building policy certainty with a special law on EBT management, which includes regulations for the development of PV development.

- Consolidating incentives such as emission reduction incentives, import facilities, and tax holidays to increase the IRR of solar power generation development.

\section{Technology}

Solar cell technology continues to develop today, with an efficiency of around $20 \%$. With this efficiency, especially in special uses, electrical and solar energy has begun to be eligible to compete with electrical energy produced from fossil or nuclear energy. Solar radiation provides energy throughout the world with different intensities. In theory, the potential of sunlight if it can be absorbed all (100\% efficiency) and converted to electrical energy, the eye for an area (1 $\mathrm{m} 2$ ) can produce 1000 watts. if it is said that the efficiency of solar cells is currently $20 \%$, it means that $1 \mathrm{~m} 2$ of solar cells can produce about $200 \mathrm{WP}$ (watt peak). Watt peak is the highest amount of electrical power that can be generated by solar cells when solar radiation is maximum, and sunlight is in a position perpendicular to the solar cells, with no cloud barriers.

Globally, electricity generation from solar energy continues to increase. Many countries have installed solar energy plants with large capacities on a massive scale, for example China, India, Mexico, to neighboring countries in Southeast Asia such as Thailand and Vietnam. This causes the investment price of solar energy to decrease every year, and Indonesia is also affected by this global impact, although not significantly. Especially with the massive production carried out by China since 2017, the price of solar panels as the main component of the system is increasingly showing a decline. Although globally there has been a decline in prices for large-scale electricity generation, the price of small-scale solar panels (rooftop solar) is still around Rp. 13,000 - Rp. 
18,000/Wp (or Rp. 13-18 million/kWp).

The challenges that will be faced related to Technology aspects are:

- Perception of solar energy as "expensive" energy.

- Need Additional tools such as inverters, and batteries to support the reliability of solar PV.

- Additional costs caused by strict local content regulations.

- There is no credit facility from the bank in indonesia which resulting that solar PV can only be enjoyed by the middle class.

- Solar pv designs that currently require a large space.

- Energy export value that is still less economical for PV solar developers and producers

The recommendations that the author conveys are:

- To intensify the aggressiveness of the off-grid solar PV market in the housing sector.

- The need for the development of national standards in this case SNI specifically for solar cell materials and their assessors.

- The government needs to restructure the value of the export value which is still considered burdensome to use PLTS Roof.

- Making research support in this case the University for the development of solar PV technology in Indonesia

- Government to cooperate with local governments to socialize and involve local investors in the development of household-based solar PV (off-grid)

\section{Conclusion}

The implementation of Solar PV in Indonesia will not run smoothly without strong synergistic cooperation between the government (regarding policies and regulations) and the business sector (BUMN or Private). The results of a thorough analysis of the strengths, weaknesses, opportunities, and threats related to the implementation of solar PV in Indonesia. Based on the results of the study found 5 success factors for the implementation of PV mini-grid, namely economic, environmental, marketing, political, social, and technological. Furthermore, from the SWOT analysis obtained: First, for social aspects related to population and human resources, each recommended strategy is an aggressive strategy. Second, for the economic aspect, which is related to potential, and the economy, each recommended strategy is an aggressive strategy and a turnaround strategy. Third, for the environmental aspect, the recommended strategy is a diversification strategy. Fourth, for the political aspects, namely regulations and incentives, the recommended strategy is a turnaround strategy. Fifth, for consumer aspects related to solar PV development, and industrialization, the recommended strategy is aggressive.

\section{Acknowledgment}

I would like to thank Professor Rinaldy Dalimi from the Faculty of Engineering, the University of Indonesia as the supervisor in this research, who has directed and been my role model, especially during my studies at the University of Indonesia. I also thank the 210 respondents for their willingness to help and provide the data needed to complete the research. In addition, I also thank Mr. Paranai Suhafsan as General Manager at PLN Distribution Banten, Mr. Imron Gazali as SVP Onshore Asset - Medco Energi International, Mr. Eka Satria COO of Medco Power International, Mr. Prof. Dr. Ir. Purwanto, DEA as Professor of Clean Technology UNDIP, Mr. Ir. Setia Budi Sasongko, DEA, PhD. - UNDIP Chemical Engineering Materials expert, Head of LPPM Undip, Prof. Dr. Ir. Bakti Jos, DEA - Professor of Separation Technology - UNDIP, Mrs. Dr. Fithriatus Shalihah S.H., M.H. as an Expert on Employment Law, Mr. Dr. Edi Asadi S.H., M.H. - Energy Law Expert, Mr. Dr. Djoko Adi Widodo, MT as the Head Lecturer (FT-Electrical Engineering Education), Mr. Faesal as the Independent Solar PV Contractor, and Ms. Maryam M Karimah as Renewable Specialist to provide recommendations to support research. It is hoped that with this research the output will be 
in the form of evaluating the implementation of solar PV in Indonesia which has been planned or implemented previously, both in terms of strengths, weaknesses, opportunities, and threats as well as providing the best strategy recommendations on target to achieve the planned energy mix target.

\section{References}

Dailami, R. (2020). Strategy menuju era eneergi terbarukan. Jakarta, Inodnesia.

Dobrotkova, Z., Surana, K., \& \& Audinet. P. (2018). The price of solar energy: Comparing competitive auctions for utility-scale solar PV in developing countries. Energy Policy, 118, 133-148.

IRENA. (2017). Renewable energy prospects: Indonesia. 14.

Kennedy, S. F. (2018). Indonesia's energy transition and its contradictions: Emerging geographies of energy and finance. Energy research \& social science, 41, 230-237.

Sugiyono, A. (2016). Outlook energi Indonesia 2015-2035: Prospek energi baru terbarukan. J Energi Dan Lingkung, 12, 87-96. 